\title{
The Use of Spices as a Media to Stimulate Children's Critical Thinking Ability while Study From Home Period
}

\author{
Erni Munastiwi ${ }^{\mathbf{1}}$ \\ 1 Prodi Pendidikan Islam Anak Usia Dini, Universitas Islam Negeri Sunan Kalijaga, Yogyakarta, Indonesia \\ e-mail:erni.munastiwi@uin-suka.ac.id
}

\section{A R T I CLE IN F O}

Article history:

Received Maret 03, 2021

Revised April 21, 2021

Accepted May 05, 202

Available online May 25, 2021

\section{Kata Kunci:}

Berpikir Kritis

Rempah-Rempah

Keywords:

Critical Thinking, Spices

\begin{abstract}
A B S T R A K
Berpikir kritis merupakan aspek penting abad 21. Adanya wabah pandemi covidbebrapa pendidik mengalami kesulitan dalam menstimlasi berpikir kritis pada anak usai dini. Namun bagi beberapa guru memanfaatkan bahan rempah-rempah di rumah sebagai media dalam menstimulasi berpikir kritis anak. oleh karena itu, penelitian ini bertujuan untuk memberikan solusi pembelajaran critical thinking dimasa pandemi covid-19. Penelitian ini menggunakan metode deskriptif kualitatif untuk mendeskripsikan penggunaan rempah-rempah dalam menstimulasi berpikir kritis Teknik pengambilan data menggunakan wawancara, observasi dan dokumentasi dengan melibatkan anak usia 5-6 tahun sejumlah 15 orang. Analisis data penelitian yaitu pengumpulan data, reduksi data, display data, dan penarikan kesimpulan dengan uji keabsahan data menggunakan teknik triangulasi. Hasil penelitian ini menunjukkan bahwa penggunaan media rempah - rempah pada aktivitas membuat jamu kunyit asam, membuat batik dari pewarna alami, dan membuat boneka melalui pendekatan saintifik dapat menstimulasi kemampuan berpikir kritis pada anak di masa study from home. Berdasarkan hal tersebut, disimpulkan bahwa penggunaan rempah-rampah dapat menstimulasi kemampuan berpikir kritis pada anak di masa study from home.
\end{abstract}

\section{A B S T R A C T}

Critical thinking is an essential aspect of the 21st century. There was an outbreak of pandemic covid-19; some educators had difficulty stimulating critical thinking in early childhood. But for some teachers used spice ingredients at home to promote the critical thinking of children. Therefore, this research aimed to provide critical thinking learning solutions during the covid 19 pandemics. This study used a qualitative descriptive method to describe the use of spices in stimulating essential thinking. The data collection technique using interviews, observations and documentation by involving children aged 5-6 years $(\mathrm{n}=$ 15). Data collection, data reduction, data display, and conclusion drawing were analyzed by testing data validity using triangulation techniques. This study showed that using spice media in making turmeric herbs acid, making batik from natural dyes, and making dolls through a scientific approach can stimulate critical thinking ability in children in the study from home. So, can be concluded that using spice media stimulate critical thinking ability in children in the study from home.

This is an open access article under the $\underline{C C B Y-S A}$ license.

Copyright @ 2021 by Author. Published by Universitas Pendidikan Ganesha.

\section{INTRODUCTION}

Until now, the covid-19 pandemic outbreak is still felt by people worldwide. Even coronavirus (covid19) has mutated into a new variant (Supriyatna et al., 2020). The virus first entered Indonesia on March 2, 2020; in just two weeks, the covid-19 virus has infected 12,776 people, and the death toll in Indonesia touches 930 (Asia, 2020). This pandemic period requires us to take care of each other's public health by keeping distance or physical restrictions (Hart, 2020). As a result of the outbreak of the covid-19 virus caused a halt in activity in various sectors of the economy, culture, including the education sector (Abidah et al., 2020). Following the president's instructions to work from home, worship from home, and learn from home, schools in Indonesia apply to study from home (Dewayani, 2020). In the covid-19 pandemic, educators are confused with the learning system that will be used during the study from home (Harnani, 2020). Education is one aspect of the development of a nation (Wulandari, 2021). If the learning system during the study from home is not immediately designed, it can lead to a lost generation (Pantjoro, 2020). The causes of the rise of lost generation are the increase in malnutrition, the decline in the health sector, the decline in education. An emergency curriculum was formed to prevent lost generation (Munajim et al., 2020). Learning activities - teaching should not stop. Therefore it takes the transformation of the learning system so that learning during the study from home is still carried out. 
Blended learning is learning used since the beginning of the pandemic (M. Zainal Arifin \&Agus Setiawan, 2020). This learning system is present because of the study from home policy that is not accompanied by the rules and rules of learning. The blended learning system becomes a solution and innovation of learning during the covid-19 pandemic (Karma et al., 2021). Based on the study results (Harahap et al., 2019), blended learning can improve students' achievements and skills. Blended learning is considered an integrated, flexible approach by combining synchronous and asynchronous digital learning (Kaur, 2020). Its application blended learning system adopts digital platforms such as zoom meeting, google meet, google classroom, and online learning tools such as laptops, mobile phones, notebooks, tablets (Huang et al., 2020). If there is no blended learning system in the covid-19 pandemic will be hampered even the worst is the cessation of learning due to the covid-19 pandemic outbreak (Haryadi, 2021). The use of blended learning using zoom meeting plays a role in e-learning learning and its existence in Indonesia (Rahayu, 2020).

Today the world is entering the 21 st century, which makes the world overgrow, digital change is so fast, the challenges of the world are getting tighter and tighter (Wijaya et al., 2016). In the 21st century, various technologies are emerging that revolutionize the human way of life (Yamin, 2019). It takes new thinking to survive in the 21 st century, and the various abilities must be possessed, one of which is the ability to think critically. Critical thinking is an essential ability that one must have because it is a milestone to get into another skill. In addition, critical thinking is also a base to improve learning methods, learning, and training, which can be made varied to suit the conditions (J.L \& Meredith, 2011). Critical thinking is the ability to identify and analyze, clarify a meaning, collect evidence, assess, conclude, consider, and make judgments on an issue (Hitchcock, 2017). In Texas, America has reformed education by increasing attention to teaching critical thinking skills to all students (Kettler, 2014). It takes a short time to form critical thinking skills in a person. Therefore critical thinking skills are suitable to be instilled early. But only a handful of schools have provided stimulation to students to the essential level of thinking. Coupled with the covid-19 pandemic outbreak that adds to the problematic situation, it is difficult here to mean that in everyday situations, critical thinking stimulation takes time, especially plus the covid-19 pandemic outbreak that makes stimulation more and more difficult. Whereas the essential stimulation of thinking is significant, considering the next 20 years the nation is in the hands of early childhood. The increasingly advanced world, should be in line with the stimulation of critical thinking skills in children. This aims to stimulate critical thinking ability can be internalized in children (Jamiah, 2012).

The selection of learning media starts from the closest to the child's environment (Abidin, 2016). Researchers chose spice media because the spice media is close to the child's context. Various spices include: (1) turmeric, (2) cardamom, (3) hazelnuts, (4) cinnamon, (5) coriander, based on research (Dyah Pramesthi et al., 2020) shows that spices can be used as a source of learning. In addition, research (Pany, 2019) shows that the use of spice media and medicinal plants in learning can develop a comprehensive view of nature. The use of spice media in learning can provide education to students about the efficacy of medicinal plants and spices. Not only that the medium of spices but also related sensory five senses namely eyes, nose to distinguish between medicinal plants with each other, tongue to feel the characteristic between spices, skin to feel the surface between spices - spices such as turmeric surface is different from the surface of cinnamon (Clark, 2019).

Based on the exposure of problems in the corner of the learning field, study from home with home spice media to stimulate children's critical thinking. Spices as a media is considered able to foster the critical thinking of children during the covid-19 pandemic. Previous research has been done to investigate and provide descriptions of the necessary thinking learning process for children aged 5-6 years during the covid-19 pandemic. However, critical thinking stimulation activities during the pandemic are still universal, such as the stimulation of critical thinking through conversations of children and parents about the reasons why learning from home (Hewi \&Asnawati, 2020; Luthfi \&Ahsani, 2020). Some studies also examine the method of critical thinking stimulation of children through scientific, cooking class, scientific, and incubate methods (Herminastiti, 2019; Husin \&Yaswinda, 2021; Priyanti \&Warmansyah, 2021; Yunita et al., 2019). However, research related to the use of spice media during the covid 19 pandemics in stimulating critical thinking of children at the age of 5-6 years. Therefore, this study aims to provide discrete information on the learning process by using spice media to stimulate children's critical thinking skills during the study from home. Through this research, it is expected that stakeholders, especially educators and parents, will apply critical thinking skills stimulation even though they are in the study from home.

\section{METHOD}

The research method is a scientific activity conducted with several stages, from topic selection to data analysis (Raco, 2010). This research is a type of qualitative research with a descriptive method (Yusuf, 2014). This research was based on natural research objects, and the key of this study is researchers (Sugiyono, 2015). This study was conducted at kindergarten P Yogyakarta in kindergarten B class with an age range of 5 -6 years 
with 15 students. The data sources in this study are students, educators, principals, and parents. The reason researchers chose the school was that the school had a vision and mission to develop critical thinking skills in students. This study explains in detail and in-depth related to the stimulation of critical thinking ability using spice media.

Data collection techniques using interviews, observations, and documentation (Creswell, 2014) researchers conducted interviews with class teachers, principals, and parents. Instrument interviews on applying spices in the manufacture of herbs, natural dyes, and dolls of spices. The researcher's observation activities follow the learning and exposure activities of herbal medicine making materials, batik, and making dolls through zoom meetings. While the documentation of researchers in collaboration with educators in documenting spice learning activities during the study form home. The instrument used to measure a child's critical thinking ability consists of 25 items, developed from Suminah et al., (2015) and Leicester \&Taylor, (2010) as seen in Table 1.

Tabel 1. Research Instrumen Grid

\begin{tabular}{|c|c|c|}
\hline Aspect & Indicator & Total Items \\
\hline $\begin{array}{l}\text { Asking question/ } \\
\text { Observing }\end{array}$ & $\begin{array}{l}\text { 1. The teacher's strategy invites to do activities using the five } \\
\text { senses } \\
\text { 2. Teacher's method of conditioning children to stay focused and } \\
\text { attentive in their activities } \\
\text { 3. Types and media of stimulation of thinking activities }\end{array}$ & 7 \\
\hline $\begin{array}{l}\text { Point of View/ } \\
\text { Questioning }\end{array}$ & $\begin{array}{l}\text { Teacher's strategy in stimulating and giving space to foster } \\
\text { curiosity }\end{array}$ & 3 \\
\hline Being Rational/ & 1. The practice of problem-solving activities & 8 \\
\hline Collecting Data & $\begin{array}{l}\text { 2. Answering curiosity } \\
\text { 3. Use of learning resources }\end{array}$ & \\
\hline Finding Out/ Associating & Ability to process information from previous curiosity & 3 \\
\hline Analysis/Communicating & $\begin{array}{l}\text { Submission of new information/ideas/knowledge that was poured } \\
\text { orally/works }\end{array}$ & 4 \\
\hline
\end{tabular}

Data analysis techniques are the stages of data collection, data reduction, data display, and conclusion drawing (Miles et al., 1994). Data collection using photos and child worksheets. Qualitative data of researchers in the form of transcripts of conversations between teachers and children through zoom meeting. After the data is collected, the researchers sort/reduce the data under the child's critical thinking stimulation activity. All data that has been collected and reduced was then displayed in the form of a scripted narrative and supplemented with conclusions. For the research results to be accurate and credible, researchers use the data validity test; the validity test of the data used was the triangulation technique (Sugiyono, 2016).

\section{RESULT AND DISCUSSION}

Based on data collection through interview techniques, observations, and documentation to the resource persons, during the study, the home school still strived to stimulate the development of children, one of which was the ability to think critically. Following the government's recommendations that had not allowed face-toface learning, the school created a home learning program with parents. The learning program was a breakthrough to keep stimulating the development of children, including stimulating critical thinking skills. Here was a school designed program:

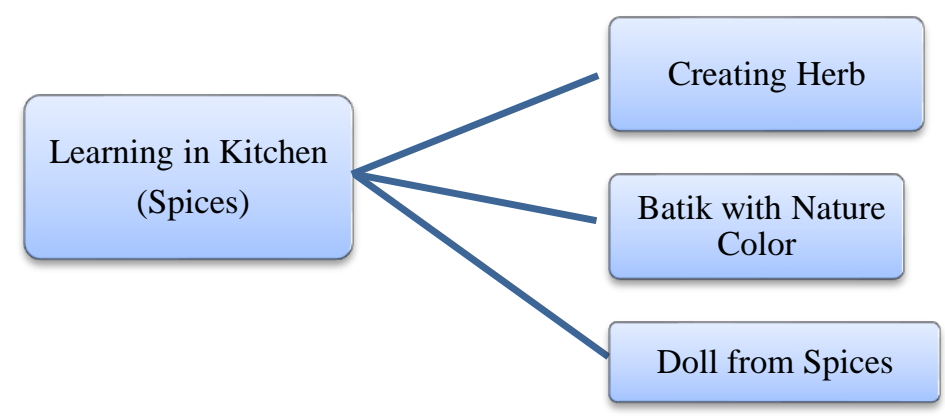

Figure 1. Schematic of the learning program 
"Learning from the Kitchen" is a school program designed to stimulate critical thinking skills in children, and it also aims to create collaboration between educators and parents. The vision and mission of kindergarten P Yogyakarta had been oriented to the development of critical thinking capabilities. During the covid-19 pandemic, a study from home was implemented that made learning done at home. This meant that parents played a role as educators who conduct assessments, evaluating, controlling. In addition, parents also serve as: (1) motivator, which aims to child's spirit to learn. (2) facilitator, to meet the children's learning needs such as stationery, storybooks, and even when the child enters elementary school and the parent cannot help the child do the task, the person facilitates the child by presenting a private teacher. (3) Mentor, with the aim of mentoring children when the child is having difficulties (Afni \&Jumahir, 2020). Here was a table of activities on the use of spices to stimulate critical thinking skills in children:

Table 2. Scientific Approach in Herb Medicine Creation Activities

\begin{tabular}{|c|c|c|}
\hline $\begin{array}{c}\text { Ability Aspect } \\
\text { Critical Thinking }\end{array}$ & $\begin{array}{l}\text { Scientific } \\
\text { Approach }\end{array}$ & Herb Medicine Creation "Kunyit Asam" \\
\hline Asking question & Observing & $\begin{array}{l}\text { Children observe spices to manufacture herbs and formulate } \\
\text { questions related to what ingredients were used to make turmeric } \\
\text { acid. }\end{array}$ \\
\hline Point of View & Questioning & $\begin{array}{l}\text { After formulating the question, the child asked the educator, } \\
\text { accompanied by the child's opinion, "Mama, why use lime, } \\
\text { instead of tamarind?" }\end{array}$ \\
\hline Being Rational & Collecting Data & $\begin{array}{l}\text { After the child asks accompanied by a reason, the child in } \\
\text { explaining continues to develop his thoughts, for example, } \\
\text { explaining "Son, what turmeric mixed with sugar tastes like?", } \\
\text { then the child experiments to gather information. Children mix } \\
\text { ingredients such as turmeric, tamarind, sugar, lime. }\end{array}$ \\
\hline Finding Out & Mengasosiasi & $\begin{array}{l}\text { After the child experiments, the child combines the information } \\
\text { that can be, researchers can find out from the child's speech } \\
\text { "Mom, it feels a bit bitter," said The Child, "Try to add sugar" } \\
\text { Mom said. The phrase indicates that the child found the results of } \\
\text { the experiment. }\end{array}$ \\
\hline Analysis & Mengomunikasikan & $\begin{array}{l}\text { After the child obtained the experiment results, the child } \\
\text { communicated to friends starting with the ingredients of making } \\
\text { turmeric acid, making sour turmeric herbs, and describing the } \\
\text { taste of the herbal medicine made. }\end{array}$ \\
\hline
\end{tabular}

Table 1. above showed that through the medium of spices, making herbal medicine "turmeric acid" can stimulate the ability to think critically in children during the study from home. Critical thinking ability can be stimulated by making herbal medicine using a scientific approach and based on experiments, and the child made his own herbal medicine accompanied by parents.

Table 2. Scientific Approach In Batik-Making Activity

\begin{tabular}{|c|c|c|}
\hline $\begin{array}{c}\text { Critical } \\
\text { Thinking Aspect }\end{array}$ & Scientific Approach & Batic with Nature Color \\
\hline Asking question & Observing & $\begin{array}{l}\text { Educators bring fabrics that have been given natural dyes in the } \\
\text { meting zoom room. Children observe the cloth and formulate } \\
\text { questions. }\end{array}$ \\
\hline Point of View & Questioning & $\begin{array}{l}\text { After the question is formulated, then the student asked the } \\
\text { educator, "Mother, what is it?" then the educator explained to } \\
\text { the child "this was a batik cloth, who wants to make batik with } \\
\text { turmeric dye?", the child asked again "Mother, how can } \\
\text { turmeric make batik?", "How do I do, mother?". At this stage, } \\
\text { the child continued to ask questions, and it also aimed to build } \\
\text { his or her thinking. }\end{array}$ \\
\hline Being Rational & Collecting Data & $\begin{array}{l}\text { Furthermore, children gathered information by experimenting } \\
\text { to make batik accompanied by parents. Children do batik, } \\
\text { ranging from giving rubber to the cloth, dipping the cloth on } \\
\text { turmeric, and drying the fabric. }\end{array}$ \\
\hline Finding Out & Associating & After the child experiments, the child combines the information \\
\hline
\end{tabular}




\begin{tabular}{|c|c|c|}
\hline $\begin{array}{c}\text { Critical } \\
\text { Thinking Aspect }\end{array}$ & Scientific Approach & Batic with Nature Color \\
\hline Analysis & Communicating & $\begin{array}{l}\text { that can be obtained. Researchers can find out the findings of } \\
\text { the child when the child gives questions or statements after the } \\
\text { experiment. "Well, the fabric changes color", "Mah, the fabric } \\
\text { becomes different". } \\
\text { After the child obtained the experiment results, the child } \\
\text { communicated to friends through the zoom meeting room. } \\
\text { Starting from providing information on what materials were } \\
\text { used, how to make, and batik results. }\end{array}$ \\
\hline
\end{tabular}

Table 2. above showed that through the medium of spices, making batik with natural dyes can stimulate the ability to think critically in children during the study from home. In this activity the teacher acted as a facilitator. The child ties his cloth and dips in turmeric liquid. Critical thinking ability can be stimulated because in making batik using scientific approach and based on experiments, the child performed the initial stage to the end of drying.

Table 3. Scientific Approach of Doll-Making Activity

\begin{tabular}{|c|c|c|}
\hline $\begin{array}{c}\text { Critical Thinking } \\
\text { Aspects }\end{array}$ & $\begin{array}{l}\text { Scientific } \\
\text { Approach }\end{array}$ & Doll-making activities \\
\hline Asking question & Observing & $\begin{array}{l}\text { The child observed ingredients consisting of turmeric, pepper, } \\
\text { cinnamon, panda eyes. Children formulated questions in their minds; } \\
\text { educators explained to students }\end{array}$ \\
\hline Point of View & Asking & $\begin{array}{l}\text { After formulating the question, the child asks the educator, } \\
\text { accompanied by the child's opinion "Mother, what do we want to } \\
\text { cook? usually my mama cooks this" asked the child. } \\
\text { At this stage, the educator informed the students if the day will make } \\
\text { dolls according to the creation of children. }\end{array}$ \\
\hline Being Rational & Collecting Data & $\begin{array}{l}\text { Furthermore, the child conducts experiments to make dolls according } \\
\text { to his wishes with the medium of spices. Educators set an example for } \\
\text { a child, but educators did not force dolls to be the same as examples. } \\
\text { Children made dolls according to their imagination. }\end{array}$ \\
\hline Finding Out & Associating & $\begin{array}{l}\text { After the child finished the making dolls process according to his } \\
\text { wishes, then the educator told them to know what findings had been } \\
\text { obtained by the child through the activity of making dolls with the } \\
\text { question "Funny, what doll is it?", then the child asked the educator } \\
\text { "Mother, why is my hand yellow like this?". From the question, the } \\
\text { child found new findings that turmeric can give a yellow color. }\end{array}$ \\
\hline Analysis & Communicating & $\begin{array}{l}\text { After the child finished experimenting with making dolls, the child } \\
\text { communicated to friends starting from the doll's name, the material } \\
\text { used to make the doll, and how to make dolls. }\end{array}$ \\
\hline
\end{tabular}

Table 3 showed that the medium of spices with making dolls from the spice medium could stimulate critical thinking ability and creative thinking ability. Critical thinking ability can be stimulated because in batik making activities using scientific approaches. Creative thinking skills can be stimulated because educators provided examples. But the protégé can make it according to the wishes of the child. Learning from the kitchen through spices can stimulate critical thinking skills in children because in its application tucked scientific approach. Not only that but essential aspects of thinking are also included in the activity. Activities on scientific approaches there are 5 among others: (1) Observing, at this stage, the child makes observations or observations with his five senses. (2) Asking, from the observation, the question arises. Questions can be in the form of development questions and recurring questions, the characteristics of the question to develop science is beginning with the question word why and how for example, "Mother, why herbal turmeric acid added with lime?" , " How to make batik using turmeric mother ?". While the question that is iteration begins with the word "so" for example "Mother, so the cloth is soaked first?". (3) Collecting information, after the child asks then enter at the next level of collecting information. Collecting information can be done with live experiments or experiments. When the child conducted experiments directly, then the experience from start to finish in the form of tools and materials, the process of making, the results of the experiments are recorded in long-term memory. Experiments are conducted in a pleasant atmosphere so that the experience that enters the long-term memory is 
more substantial (Porter \&Hernacki, 1999). (4) Associate, combining basic knowledge with new knowledge that has just been acquired. (5) Communicating, is the peak stage where the child communicates the experiment results to others.

In line with the scientific approach, the stimulation of critical thinking ability has 5 similar aspects: (1) Asking a question, this aspect went into the second scientific approach that was questioning. (2) Point of view, this aspect was a development on the second scientific approach activity asking questions and accompanied by opinions. (3) Being rational, this aspect went into the third scientific approach activity: gathering information by experimenting. By experimenting then the child can prove something real and sensible. (4) Finding, this aspect of the findings went into the fourth scientific approach that is associate. The child discovered something new after the child experiments. (5) Analysis, this aspect also entered the fourth scientific approach that was osciating because when the child associate or combine old knowledge with new knowledge, there will be an investigation of new knowledge (Leicester \&Taylor, 2010). The above exposure shows that there was a relationship between critical thinking aspects and scientific approaches. Here was a schematic of the relationship between scientific approach activities and aspects of critical thinking ability:

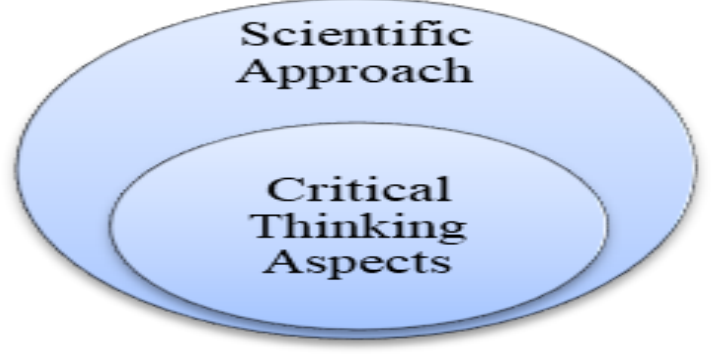

Figure 2. The relation between scientific approach and critical thinking aspects

The scheme showed that activities designed with a scientific approach could stimulate critical thinking skills. In line with the research (Triyani et al., 2019) shows that the use of scientific approaches affects the critical thinking ability of the child. How important it was to stimulate critical thinking skills in early childhood, considering the increasingly sophisticated world. Then critical thinking stimulation was given as early as possible. Designing learning programs and creating learning that aimed to stimulate critical thinking was a contribution in the world of education to prepare children to compete in the 21 st century.

Critical thinking skills were essential as attributes to success in the 21 st century. The essential emphasis of thinking learning from an early age is expected from early age children can get used to communicative, collaborative, creative, innovative, critical and analytical thinking, and later solve real-world problems effectively (ŽivkoviL;, 2016). Providing innovative and creative teaching of teachers who can stimulate critical thinking of children optimally, so that optimal aspects of critical thinking, children can become competent critical thinkers (Fernández-Santín \&Feliu-Torruella, 2020). Thus, the covid-19 pandemic that had spread worldwide, the role of educators in providing innovative teaching will not hinder the optimization of children's critical thinking despite learning from home. Critical thinking as a directed metacognitive process can improve the logical way of solving various real-world problems (Dwyer et al., 2014). Critical thinking stimulation from an early age is expected to equip children in adapting to a new environment, have a dynamic mindset, and be communicators who can see from various directions. Therefore, the role of educators in equipping children in the 21 st-century era with problem-solving skills, communication, creativity, critical and collaborative thinking is part of modern society (Teo, 2019). It was equipping students to compete in the modern era. The role of teachers is indispensable as part of the agents of modern society change and education reform. The condition of pandemic covid 19, the competence of teachers in utilizing Information and Communication Technology (ICT) is needed in the continuity of learning. The use of ICT as part of the skills of the 21 st century is reflected in the ability to survive in the conditions of the development of the times and competition of the outside world (Widyanti, 2017). The implementation of pandemic learning online reflects modern society of the 21 st century that can survive in various conditions and situations. Thus, this study form home study through online learning by utilizing the application of learners and parental involvement by utilizing spices to stimulate critical thinking of early childhood students.

\section{CONCLUSION}

The use of spice media in making turmeric acid herbs, the activity of making batik with natural dyes, and the activity of making dolls by applying scientific approaches that include observing, questioning, gathering 
information, associate, and communicating can stimulate critical thinking skills in children. This because there was a relationship between scientific approach activities and aspects of critical thinking ability. Aspects of critical thinking ability were in a scientific approach. So when the activity was designed using a scientific approach, its critical thinking ability was also stimulated. The three activities were accompanied by parents so that critical thinking skills in children remain stimulated during the study from home.

\section{REFERENCES}

Abidah, A., Hidaayatullaah, H. N., Simamora, R. M., Fehabutar, D., \& Mutakinati, L. (2020). The Impact of Covid-19 to Indonesian Education and Its Relation to the Philosophy of "Merdeka Belajar." Studies in Philosophy of Science and Education, 1(1), 38-49. https://doi.org/10.46627/sipose.v1i1.9.

Abidin, Z. (2016). Penerapan Pemilihan Media Pembelajaran. Edcomtech, 1(1), 9-20.

Afni, N., \& Jumahir, J. (2020). Peranan Orang Tua Dalam Meningkatkan Prestasi Belajar Anak. Musawa: Journal for Gender Studies, 12(1), 108-139. https://doi.org/10.24239/msw.v12i1.591.

Asia, chanel news. (2020). "Indonesia's health system on the brink as coronavirus looms."

Clark, R. (2019). Assessing the impact of reflective activities in digital and analog electronics courses. IEEE Transactions on Education, 62(2), 141-148. https://doi.org/10.1109/TE.2018.2885720.

Creswell, J. W. (2014). Research Design (Qualitative, Quantitative, and Mixed Methods Approaches). In Society.

Dewayani, T. (2020). Bekerja dari Rumah (Work From Home) Dari Sudut Pandang Unit Kepatuhan Internal.

Dwyer, C. P., Hogan, M. J., \& Stewart, I. (2014). An integrated critical thinking framework for the 21 st century. Thinking Skills and Creativity, 12, 43-52. https://doi.org/10.1016/j.tsc.2013.12.004.

Dyah Pramesthi, Isyana Ardyati, \& Agus Slamet. (2020). Potensi Tumbuhan Rempah dan Bumbu yang Digunakan dalam Masakan Lokal Buton sebagai Sumber Belajar. Biodik, 6(3), 225-232. https://doi.org/10.22437/bio.v6i3.9861.

Fernández-Santín, M., \& Feliu-Torruella, M. (2020). Developing critical thinking in early childhood through the philosophy of Reggio Emilia. Thinking Skills and Creativity, 37, 100686. https://doi.org/10.1016/j.tsc.2020.100686.

Harahap, F., Nasution, N. E. A., \& Manurung, B. (2019). The Effect of Blended Learning on Student's Learning Achievement and Science Process Skills in Plant Tissue Culture Course. International Journal of Instruction.

Harnani, S. (2020). Efektivitas Pembelajaran Daring Di Masa Pandemi Covid-19. BDK Kemenag.

Hart, J. L. (2020). Family-Centered Care During the COVID-19 Era. Journal of Pain and Symptom Management, 60(2). https://doi.org/10.1016/j.jpainsymman.2020.04.017.

Haryadi, R. (2021). Pendidikan dalam Bahaya, 25 Anak SMA Nikah karena Wabah. Gatra.com.

Herminastiti, R. (2019). Peran Kegiatan Fun cooking dan Country Project dalam Kemampuan Matematika Awal dan Berpikir Kritis Anak Usia Dini. KINDERGARTEN: Journal of Islamic Early Childhood Education, 2(1), 6. https://doi.org/10.24014/kjiece.v2i1.6993.

Hewi, L., \& Asnawati, L. (2020). Strategi Pendidik Anak Usia Dini Era Covid-19 dalam Menumbuhkan Kemampuan Berfikir Logis. Jurnal Obsesi: Jurnal Pendidikan Anak Usia Dini, 5(1), 158. https://doi.org/10.31004/obsesi.v5i1.530.

Hitchcock, D. (2017). Critical Thinking as an Educational Ideal. Argumentation Library, 30(April), $477-497$. https://doi.org/10.1007/978-3-319-53562-3_30.

Huang, R. H., Liu, D. J., \& Zhan, T. (2020). Guidance on Flexible learning during Campus Closures: ensuring course quality of higher education in COVID-19 outbreak. In Beijing: Smart Learning Institute of Beijing Normal University. researchgate.net.

Husin, S. H., \& Yaswinda, Y. (2021). Analisis Pembelajaran Sains Anak Usia Dini di Masa PANDEMI Covid19. Jurnal Basicedu, 5(2), 581-595. https://doi.org/10.31004/basicedu.v5i2.780.

J.L, S., \& Meredith, K. . (2011). Classrom of wonder and wisdom: reading, writing and critical thinking for the 21st century. In Sage Company (p. 23).

Jamiah, Y. (2012). Internalisasi Nilai-nilai Berpikir Kritis Melalui Pengembangan Model Pembelajaran Konsep Matematika Kreatif Pada Pendidikan Anak Usia Dini. Jurnal Pendidikan Dan Pembelajaran (JPP), 19(2), 229-236.

Karma, I., Darma, I. K., \& Santiana, I. (2021). Blended Learning is an Educational Innovation and Solution During the COVID-19 Pandemic. International Research Journal of Engineering, IT \& Scientific Research.

Kaur, M. (2020). Blended Learning: Need of the Hour. In academiccanvas.highereduhry.com.

Kettler, T. (2014). Critical Thinking Skills Among Elementary School Students. Gifted Child Quarterly, 58(2), 
127-136. https://doi.org/10.1177/0016986214522508.

Leicester, M., \& Taylor, D. (2010). Critical Thinking Across the curriculum; Developing critical thinking skills, literacy and philosophy in the primary classroom.

Luthfi, E., \& Ahsani, F. (2020). Strategi Orang Tua dalam Mengajar dan Mendidik Anak dalam Pembelajaran At The Home Masa Pandemi Covid-19. In Al Athfal: Jurnal Kajian Perkembangan Anak dan Manajemen Pendidikan Usia Dini (Vol. 3, Issue 1). https://ejournal.stainupwr.ac.id/

M. Zainal Arifin, \& Agus Setiawan. (2020). Strategi Belajar Dan Mengajar Guru Pada Abad 21 . Indonesian $\begin{array}{lllll}\text { Journal of } & \text { Instructional }\end{array}$ https://journal.kurasinstitute.com/index.php/ijit/article/view/45.

Miles, M. B., Huberman, A. M., \& Saldana, J. (1994). Qualitative Data Analysis: A Methods Sourcebook. Library of Congress Cataloging-in-Publication Data.

Munajim, A., Barnawi, B., \& Fikriyah, F. (2020). Pengembangan Kurikulum Pembelajaran di Masa Darurat. DWIJA CENDEKIA: Jurnal Riset Pedagogik, 4(2), 285. https://doi.org/10.20961/jdc.v4i2.45288.

Pantjoro, T. (2020). Potensi Lost Generation Akibat Pandemi Covid-19. YBB.

Pany, P. (2019). Using students' interest in useful plants to encourage plant vision in the classroom. Plants People Planet, 1(3), 261-270. https://doi.org/10.1002/ppp3.43.

Porter, B. De, \& Hernacki, M. (1999). Quantum Learning (S. Meutia (ed.); 5th ed.). Kaifa.

Priyanti, N., \& Warmansyah, J. (2021). Improving Critical Thinking Skills of Early Childhood through Inquiry Learning. Jurnal Obsesi: Jurnal Pendidikan Anak Usia Dini, 5(2), 2241-2249. https://doi.org/10.31004/obsesi.v5i2.1168.

Raco. (2010). Metode Penelitian Kualitatif: Jenis, Karakteristik,, dan Keunggulannya. Grasindo.

Rahayu, D. (2020). Students' E-Learning Experience through a Synchronous Zoom Web Conference System. Journal of ELT Research: The Academic Journal ....

Sugiyono. (2015). Cara Mudah Menyusun Skripsi, Tesis, dan Disertasi (A. Nuryanto (ed.); 3rd ed.). Alfabeta.

Sugiyono. (2016). Metode Penelitian Kuantitatif, Kualitatif Dan R\&D (24th ed.). Alfabeta.

Suminah, E., Nugraha, A., Lestari, G. D., Mareta, \& Wahyuni, M. (2015). Kurikulum Pendidikan Anak Usia Dini. Apa, Mengapa, dan Bagaimana. Direktorat Pembinaan Pendidikan Anak Usia Dini, 18.

Supriyatna, A., Kinasih, I., Virakawugi Darniwa, A., Jaenudin, M., Sains dan Teknologi, F., Sunan Gunung Djati Bandung, U., \& Quran dan Hadist, A. (2020). Evolusi SARS-CoV-2 dalam Perspektif Wahyu Memandu Ilmu (WMI). 1-2.

Teo, P. (2019). Teaching for the 21st century: A case for dialogic pedagogy. In Learning, Culture and Social Interaction (Vol. 21, pp. 170-178). Elsevier Ltd. https://doi.org/10.1016/j.lcsi.2019.03.009.

Triyani, T., Herayanti, L., \& Gummah, S. (2019). Effect of Scientific Approach toward Students' Critical Thinking Skills. Lensa : Jurnal Kependidikan Fisika, 7(1), 15. https://doi.org/10.33394/j-lkf.v7i1.1906

Widyanti, T. (2017). Keterampilan Belajar Abad 21 Untuk Melatih Berpikir Kritis Melalui Sistem Pembelajaran Berbasis Ict. Administrasi Pendidikan: Jurnal Ilmiah Mahasiswa Pascasarjana, 5(2), 143-148. https://jurnal.unigal.ac.id/index.php/adpen/article/view/2031.

Wijaya, E. Y., Sudjimat, D. A., \& Nyoto, A. (2016). Transformasi Pendidikan Abad 21 Sebagai Tuntutan. Jurnal Pendidikan, 1, 263-278.

Wulandari, D. R. (2021). Android application innovation as the indonesian basic spices learning media. In Journal of Physics: Conference Series (Vol. 1833, Issue 1). https://doi.org/10.1088/17426596/1833/1/012062.

Yamin, M. (2019). Information technologies of 21st century and their impact on the society. International Journal of Information Technology (Singapore), 11(4), 759-766. https://doi.org/10.1007/s41870-01900355-1.

Yunita, H., Meilanie, S. M., \& Fahrurrozi, F. (2019). Meningkatkan Kemampuan Berpikir Kritis melalui Pendekatan Saintifik. Jurnal Obsesi: Jurnal Pendidikan Anak Usia Dini, 3(2), 425. https://doi.org/10.31004/obsesi.v3i2.228.

Yusuf, A. M. (2014). Metode Penelitian Kuantitatif, Kualitatif \& Penelitian Gabungan (Suwito (ed.); 1st ed.). Prenadamedia Group.

ŽivkoviL, S. (2016). A Model of Critical Thinking as an Important Attribute for Success in the 21st Century. Procedia - Social and Behavioral Sciences, 232, 102-108. https://doi.org/10.1016/j.sbspro.2016.10.034. 